\title{
Application Fate of Sewage and Industrial Effluents on Soil and Plant Health under Karnal District of Haryana, India
}

\author{
Hanumant Singh $^{1 *}$, D.S. Dahiya ${ }^{1}$, Devraj ${ }^{1}$, Md. Sarware Alam ${ }^{1}$, \\ Abhinaw Kumar Singh ${ }^{1}$ and Y.Y. Giri ${ }^{2}$ \\ ${ }^{1}$ Department of Soil Science, CCS HAU, Hisar-125004, Haryana, India \\ ${ }^{2}$ Department of Soil Science, PJTSAU, Hyderabad-500030, Telangana, India \\ *Corresponding author
}

\section{Keywords \\ Effect, Sewage, Industrial Effluents, Soil, Plant and Health}

\section{Article Info}

Accepted:

26 August 2017

Available Online:

10 September 2017

\section{A B S T R A C T}

The present investigation, a field survey experiment was conducted during summer season of 2015 in Karnal district of Haryana by Department of Soil Science, Chaudhary Charan Singh Haryana Agricultural University, Hisar. The treatments consisted of six irrigation sites; in which five irrigations sites with sewage and industrial effluents and one irrigated site with tube well water. The treatments were replicated three times under randomized block design, with soils and crops plant. Effect of continuous application of sewage and industrial effluent on soil properties, nutrients status and pollutant elements in soils and plants in the adjoining areas of Karnal district of Haryana was ascertained. An appreciable increase in organic carbon, available N, P, K contents was recorded in the sewage and industrial effluents irrigated soils. $\mathrm{pH}$ and Electrical conductivity of sewage and industrial effluents irrigated soils was much higher than tube well water irrigated soils. Application of sewage and industrial effluents resulted in the accumulation of heavy metals in surface soil. he mean contents of micronutrients and heavy metals viz., $\mathrm{Fe}, \mathrm{Zn}, \mathrm{Mn}, \mathrm{Cu}, \mathrm{Pb}, \mathrm{Cd}$, $\mathrm{Cr}$, and $\mathrm{Ni}$ in the soils irrigated with sewage and industrial effluents was significantly higher respect to tube-well water. The concentration of micronutrients and heavy metals viz., $\mathrm{Fe}, \mathrm{Zn}, \mathrm{Mn}, \mathrm{Cu}, \mathrm{Pb}, \mathrm{Cd}, \mathrm{Cr}$ and $\mathrm{Ni}$ in leafy plants grown under sewage and industrial effluents application was higher as compared to cereal crops and then tube well water irrigation plants.

\section{Introduction}

The sewage and industrial effluents provides farmers with a nutrient enriched water supply and society with a reliable and inexpensive system for wastewater treatment and disposal. In India also being a cheap source of irrigation farmers are applying this water to their fields. Rapid industrialization, population explosion and more urbanization in India have created enormous problems of environmental pollution in terms of generating the variable quantity and quality of solid and liquid wastes. In developing countries, there has not been much emphasis on the installation of sewage treatment plants and all the industrial effluents are generally discharged in to the sewage system.

In developing countries, there has not been much emphasis on the installation of sewage treatment plants and all the industrial effluents are generally discharged in to the sewage system. 
The sewage waters are used as potential source irrigation for raising vegetables and fodder crops around the sewage disposal sites which are directly or indirectly consumed by human beings. Soil contamination by sewage and industrial effluents has affected adversely both soil health and crop productivity. Sewage and industrial effluents are the rich sources of both beneficial as well as harmful elements.

Since some of these effluents are a rich source of plant nutrients, therefore soil provides the logical sink for their disposal. But many untreated and contaminated sewage and industrial effluents may have high concentration of several heavy metals such $\mathrm{Cd}, \mathrm{Ni}, \mathrm{Pb}$ and $\mathrm{Cr}$ (Antil \& Narwal, 2008). Their continuous disposal on agricultural soils has resulted in soil sickness and accumulation of some of the toxic metals in soil (Kharche et $a l ., 2011$ ) which may pose serious human and animal health.

Sewage and Industrial effluents are a rich source of plant nutrients; therefore soil provides the logical sink for their disposal. But many untreated and contaminated sewage and industrial effluents may have high concentration of several heavy metals such $\mathrm{Pb}, \mathrm{Cd}, \mathrm{Cr}$ and $\mathrm{Ni}$.

Field study was conducted in Unchaswada and Ganzogariarea, to evaluate the effects of using sewage and industrial effluents to irrigate the soils near ground water wells in this region. Many quality parameters like $\mathrm{pH}$, Electrical Conductivity (EC), Organic Carbon (OC), Nitrogen (N), Phosphorus (P), Potassium (K), Carbonate $\left(\mathrm{CO}_{3}{ }^{2-}\right)$, Bicarbonate $\left(\mathrm{HCO}_{3}{ }^{-}\right), \quad$ Calcium $\left(\mathrm{Ca}^{2+}\right)$, Magnesium $\left(\mathrm{Mg}^{2+}\right)$, Chloride $\left(\mathrm{Cl}^{-}\right)$, Sulphate $\left(\mathrm{SO}_{4}{ }^{2-}\right)$, Sodium $\left(\mathrm{Na}^{+}\right)$, Iron $(\mathrm{Fe})$, Manganese $(\mathrm{Mn})$, Zinc $(\mathrm{Zn})$, Copper $(\mathrm{Cu})$, Lead $(\mathrm{Pb})$, Cadmium (Cd), Chromium (Cr), and Nickel (Ni)are analysed.

\section{Materials and Methods}

To evaluate the effect of Sewage and Industrial effluents on soils and plants health, an industrial town of Haryana, namely Karnal was selected. Collection of Sewage and Industrial effluents from areas falling under city of Karnal is under the administrative control of the Public Health Department. A pumping station is located in the area near the villages Unchasiwana and Ganjogarhig. The Sewage and Industrial effluents are discharged into a linked channel that carries the Sewage and Industrial effluents.

Farmers owning land along this channel are making use of this sewage and industrial effluents for irrigation purposes and the process is going on unknown period of time (informally reported 50 years). Soils of the areas are loamy sand, silty loam and sandy loam nature expressed. There the wheat, berseem, vegetables and seasonal flowers production sites along the channel are irrigated with sewage and industrial effluents. Soil samples from field irrigated with sewage and industrial effluents were collected from five sites at a depth of $0-15 \mathrm{~cm}$ and Soil samples from field irrigated with tube well waters were collected from one site at a depth of $0-15 \mathrm{~cm}$. After collection, the sewage and industrial effluents and tube well waters were stored in neutral plastic bottles. Several parameters were measured separately in soils and liquid west materials likepH and Electrical conductivity (Jackson, 1973), Organic Carbon (Walkley and Black's, 1934), Nitrogen (Subbiah and Asija, 1956), Phosphorus (Olsen et al., 1954), Potassium, Calcium, Magnesium and Sodium (Jackson, 1973), Carbonate, Bicarbonate and Chloride (Richards, 1954), Sulphate (Chensin and Yien, 1950), Nitrate $\left(\mathrm{NO}_{3}{ }^{-}\right)$, micronutrients viz., Iron (Fe), Magnesium (Mn), Copper $(\mathrm{Cu})$, Zinc $(\mathrm{Zn})$, and heavy metals viz., Lead $(\mathrm{Pb})$, Nickel (Ni), Cadmium (Cd), Chromium 
(Cr) were determined by using atomic absorption spectrophotometer (Lindsay and Norvell, 1978) by their standard methods. Plants samples were analised for total nitrogen by calorimetric method (Lindner, 1944), total phosphorus by ammonium vanadomolybdo-phosphoric acid yellow colour method (Koenig and Johnson, 1942), total potassium by flame photometry method (Isaac and Kerber, 1971), micronutrients (Fe, $\mathrm{Zn}, \mathrm{Mn}, \mathrm{Cu})$ and heavy metals $(\mathrm{Pb}, \mathrm{Cd}, \mathrm{Cr}$, $\mathrm{Ni}$ ) by atomic absorption spectro-photometry method (Isaac and Kerber, 1971).

\section{Results and Discussion}

The chemical composition of sewage and industrial effluents and tube well waters were assessed for $\mathrm{pH}, \mathrm{EC}, \mathrm{OC}, \mathrm{P}, \mathrm{K}^{+}, \mathrm{Ca}^{2+}, \mathrm{Mg}^{2+}$, $\mathrm{Na}^{+}, \mathrm{CO}_{3}{ }^{2-}, \mathrm{HCO}_{3}{ }^{-}, \mathrm{Cl}^{-}, \mathrm{SO}_{4}{ }^{2-}, \mathrm{NO}_{3}{ }^{-}, \mathrm{Fe}, \mathrm{Mn}$, $\mathrm{Cu}, \mathrm{Zn}, \mathrm{Pb}, \mathrm{Ni}, \mathrm{Cd}$, and $\mathrm{Cr}$ contents (Table 1). All the sewage and industrial effluents and tube well waters were alkaline in reaction.
The $\mathrm{pH}$ of sewage and industrial effluents (8.47 - 8.52) was higher than the tube well waters (8.27) and its electrical conductivity $(1.56-1.71)$ and organic carbon $(0.16-0.14)$ was also higher than tube well waters (1.26) (0.03). The concentration of almost all nutrients elements tended to be higher in sewage and industrial effluents respect to tube well water.

\section{Effect of sewage and industrial effluents irrigation on soil properties}

The experimental soil irrigated with sewage and industrial effluents, the $\mathrm{pH}$ of soil was found to be slightly decreased after application of sewage and industrial effluents. Due to residual alkalinity in sewage and industrial effluents, the soils have been rendered slightly alkaline. Slight reduction in $\mathrm{pH}$ was noticed at sites receiving higher proportion of sewage and industrial effluents for irrigation (Abou et al., 2008).

Table.1 Chemical composition of sewage and industrial effluents and tube well waters

\begin{tabular}{|c|c|c|c|}
\hline $\begin{array}{l}\text { Parameters } \\
\mathrm{I}^{\text {st }} \mathrm{II}^{\text {nd }}\end{array}$ & Sewage and & effluents & Tube well waters \\
\hline $\mathrm{pH}$ & 8.47 & 8.52 & 8.27 \\
\hline $\mathrm{EC}\left(\mathrm{dSm}^{-1}\right)$ & 1.56 & 1.711 .26 & \\
\hline $\mathrm{OC}\left(\mathrm{me} \mathrm{L}^{-1}\right)$ & 0.16 & 0.14 & 0.03 \\
\hline $\mathrm{P}\left(\mathrm{me} \mathrm{L}^{-1}\right)$ & 0.29 & 0.46 & 0.11 \\
\hline $\mathrm{K}^{+}\left(\mathrm{me} \mathrm{L}^{-1}\right)$ & 1.14 & 2.230 .10 & \\
\hline $\mathrm{Ca}^{2+}\left(\mathrm{me} \mathrm{L}^{-1}\right)$ & 1.99 & 2.11 & 1.06 \\
\hline $\mathrm{Mg}^{2+}\left(\mathrm{me} \mathrm{L}^{-1}\right)$ & 5.98 & 6.39 & 3.18 \\
\hline $\mathrm{Na}^{+}\left(\mathrm{me} \mathrm{L}^{-1}\right)$ & 6.40 & 8.18 & 6.31 \\
\hline $\mathrm{CO}_{3}{ }^{2-}\left(\mathrm{me} \mathrm{L}^{-1}\right)$ & - & - & - \\
\hline $\mathrm{HCO}_{3}^{-}\left(\mathrm{me} \mathrm{L}^{-1}\right)$ & 5.48 & 6.58 & 2.60 \\
\hline $\mathrm{Cl}^{-}\left(\mathrm{me} \mathrm{L}^{-1}\right)$ & 6.35 & 7.30 & 5.88 \\
\hline $\mathrm{SO}_{4}^{2-}\left(\mathrm{me} \mathrm{L}^{-1}\right)$ & 2.86 & 3.80 & 2.27 \\
\hline $\mathrm{NO}_{3}^{-}\left(\mathrm{me} \mathrm{L}^{-1}\right)$ & 0.45 & 0.81 & 0.42 \\
\hline $\mathrm{Fe}\left(\mathrm{me} \mathrm{L}^{-1}\right)$ & 10.14 & 6.25 & 2.56 \\
\hline $\operatorname{Mn}\left(\mathrm{me} \mathrm{L}^{-1}\right)$ & 0.24 & 0.19 & 0.15 \\
\hline $\mathrm{Cu}\left(\mathrm{me} \mathrm{L}^{-1}\right)$ & 0.21 & 0.20 & 0.19 \\
\hline $\mathrm{Zn}\left(\mathrm{me} \mathrm{L}^{-1}\right)$ & 0.16 & 0.15 & 0.12 \\
\hline $\mathrm{Pb}\left(\mathrm{me} \mathrm{L}^{-1}\right)$ & 0.13 & 0.12 & 0.10 \\
\hline $\mathrm{Ni}\left(\mathrm{me} \mathrm{L}^{-1}\right)$ & 0.12 & 0.09 & 0.02 \\
\hline $\mathrm{Cd}\left(\mathrm{me} \mathrm{L}^{-1}\right)$ & 0.31 & 0.32 & 0.30 \\
\hline $\mathrm{Cr}\left(\mathrm{me} \mathrm{L}^{-1}\right)$ & - & - & - \\
\hline
\end{tabular}


Table. 2 Chemical properties, nutrients, and heavy metals status of soils irrigated with sewage and industrial effluents and tube well water

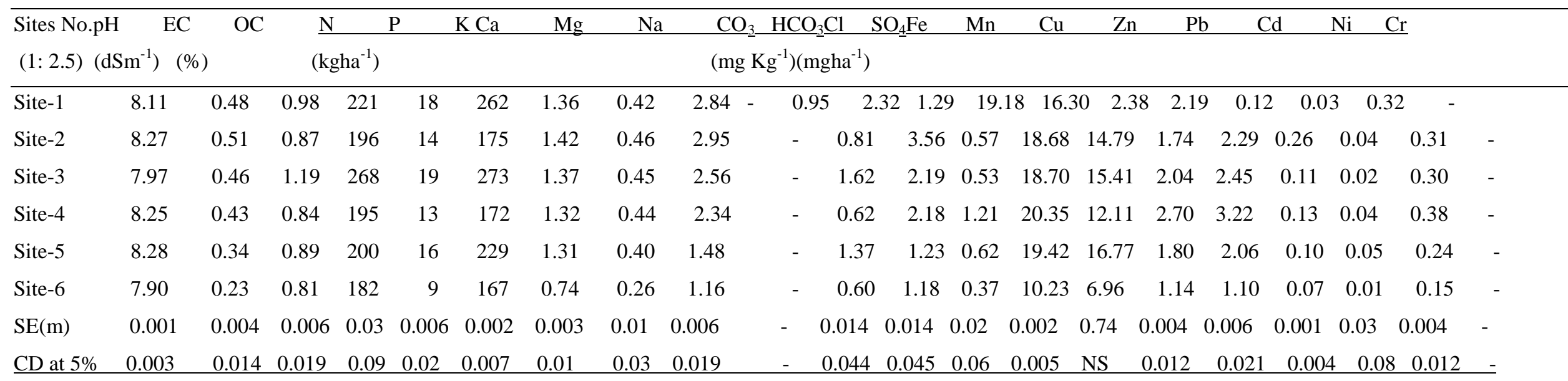

Site-1 to 5 (irrigated with sewage and industrial effluents), Site-6 (tube well water), NS - non significant,

Table.3 Nutrients and heavy metals content in plants samples after irrigation with sewage and industrial effluents and tube well water

\begin{tabular}{|c|c|c|c|c|c|c|c|c|c|c|c|c|}
\hline \multicolumn{13}{|c|}{ Crops plant } \\
\hline Sites No. & Berseem & 1.35 & 0.21 & 1.06 & 265.40 & 31.00 & 57.10 & 3.85 & 1.90 & 1.45 & 16.00 & - \\
\hline Site-2 & Wheat & 0.90 & 0.18 & 1.11 & 156.30 & 28.10 & 9.75 & 5.05 & 1.80 & 1.15 & 8.61 & - \\
\hline Site-3 & Cauliflower & 2.34 & 0.49 & 1.41 & 208.60 & 63.35 & 5.30 & 4.05 & 1.45 & 0.85 & 5.01 & - \\
\hline Site-4 & Wheat & 0.22 & 0.25 & 1.69 & 152.10 & 25.70 & 13.02 & 5.89 & 1.85 & 1.10 & 4.98 & - \\
\hline Site-5 & Marigold & 4.91 & 0.53 & 1.85 & 508.50 & 62.40 & 45.95 & 14.50 & 1.32 & 0.35 & 8.16 & - \\
\hline Site-6 & Wheat & 0.11 & 0.16 & 0.58 & 148.50 & 22.90 & 0.70 & 2.75 & 1.17 & 0.20 & 2.12 & - \\
\hline $\mathrm{SE}(\mathrm{m})$ & & 0.007 & 0.005 & 0.004 & 0.22 & 0.11 & 0.16 & 0.003 & 0.004 & 0.005 & 0.20 & - \\
\hline $\mathrm{CD}$ at $5 \%$ & & 0.023 & 0.017 & 0.014 & 0.71 & 0.34 & 0.50 & 0.009 & 0.013 & 0.015 & 0.64 & - \\
\hline
\end{tabular}


Electrical conductivity of experimental soil was higher if applied of sewage and industrial effluents than tube well water irrigated soils because sewage and industrial effluents content many types soluble and exchangeable salt (Omran et al., 2010).

High load of organic matter in sewage and industrial effluents has resulted in an improvement in organic carbon in soils. The organic carbon of sewage and industrial effluents irrigated soil was found enhanced more than tube well water irrigated soil as presented in tables 2 and 3. Organic carbon content of sewage and industrial effluents fed soils were found to be slightly higher than in the soil irrigated through tube well water and this is possible due to incorporation of organic matter through sewage and industrial effluents. The significance difference was observed in the organic carbon in the soils irrigated with sewage and industrial effluents to that of tube well water. According to Antil and Narwal (2008) continuous application of sewage and industrial effluents for irrigation increases soil EC and OC, whereas it decreases soil $\mathrm{pH}$ and Subramani et al., (2014) reported lower $\mathrm{pH}$ and higher OC in soils irrigated with sewage water as compared to those irrigated with tube well water.

The surface soil was also richer in nutrients when application of sewage and industrial effluents than tube well water application. The effect of sewage and industrial effluents on fertility status of soil after harvest of crops was observed to be significant for available nitrogen, phosphorus and potassium in table 3. Amongst the soils recorded significant available nitrogen, phosphorus and potassium as compared to soils irrigation with tube well water as depicted in table 3. This indicated that sewage and industrial effluents irrigation provides the essential nutrients to the crops as well as improved fertility status of soils as reported by Gwenzi and munondo, (2008). Water soluble cations viz., Calcium, Magnesium and sodium concentrations of sewage and industrial effluents irrigated soils indicated that significantly higher then tube well water irrigated soils. The level of cations in the soil irrigated with sewage and industrial effluents varied differently from tube well water irrigated sites. In the present study, the water soluble anions $\left(\mathrm{HCO}_{3}{ }^{-} \mathrm{Cl}^{-}, \mathrm{SO}_{4}{ }^{2-}\right)$ in the sewage and industrial effluents irrigated soils increased with the increase in sewage and industrial effluents irrigations. The sewage and industrial effluents application showed significant effect on water soluble anions $\left(\mathrm{HCO}_{3}{ }^{-} \mathrm{Cl}^{-}, \mathrm{SO}_{4}{ }^{2-}\right)$ of the soils in comparison to tube well water irrigated soils (Kumar et al.,2011).

The experimental sites showed significant improvement in fertility level of soils with respect to micronutrients as recorded after harvest of crops (Table 3). The improvement in micronutrients status in soils might be due to irrigation of soils with sewage and industrial effluents. The DTPA (Diethyl enetriaminepenta acetic acid) extractable metals consisting of $\mathrm{Fe} \mathrm{Mn}, \mathrm{Zn}, \mathrm{Cu}, \mathrm{Pb}, \mathrm{Cd}$, $\mathrm{Cr}$, and $\mathrm{Ni}$ after harvest were found to be slightly higher than tube well water irrigated soils. The findings were in conformity with the earlier studies reported by Zen et al., (2013).

\section{Nutrients and heavy metals content in plants samples}

Application of sewage and industrial effluents, changes in nutrients content of soils also reflected in content by crops plant growing at these sites. Higher content of nitrogen, phosphorus and potassium were monitored in their plants when grown on soils irrigated with sewage and industrial effluents and there was constant decline in their 
concentrations in plants grown from fields lying at a distance from the disposal point and from the channel. Higher accumulation of micronutrients and heavy metals in plants was also observed in sewage and industrial effluents irrigated crops. The content of micronutrients and heavy metals was also decline with tube well water irrigated plants sample. Thus this analysis shows that the soil irrigated with different proportion of sewage and industrial effluents increased micronutrients and heavy metals contents in plants than under tube well water irrigated plants. Khan et al., (2014) have reported similar observations for soils irrigated with sewage and industrial effluents from IARI.

The results from the sites under study where sewage and industrial effluents is being used for about some decades showed the enrichment of soils with organic carbon and nutrients accumulation in soils and plants. Thus, the efficient application of sewage and industrial effluents can effectively increase water resource for irrigation and may prove to be a boon for agriculture production.

\section{References}

Antil, R.S., and Narwal, R.P. 2008. Influence of sewer water and industrial effluents on soil and plant health. In: Groundwater resources: Conservation and management, Department of Environmental Science and Engineering, GJU Science and Technology Hisar, India. Pp.37-46.

Chesnin, L., and Yien, C. H. 1950. Turbidimetric determination of available sulphur. Soil Science Society of America proceedings 15, 149-151.

Gwenzi, W., Munondo, R. 2008. Long-term impacts of pasture irrigation with treated sewage effluent on nutrient status of a sandy soil in Zimbabwe. Nutrient Cycling in Agroecosystems.
82(2):197-207.

Isaac, R.A., and Kerber, J.O. 1971. Atomic Absorption and Flame Photometry: Technique and Uses in Soil, Plant and Water Analysis. In L. M. Walsh (ed) Instrumental Methods of Analysis of Soils and Plant Tissue. Soil Sci. Soc. Amer., Madison, Wisconsin, pp17-37.

Jackson, M.L., 1973. Soil chemical Analysis, Prentice Hall India Pvt. Ltd., New Delhi.

Khan, Z.I., Zahara Bibi Kafeel Ahmed Muhammed Asraf 2014. Appraisal of heavy metal concentrations in edible vegetable Abelmoschus esculentus (Lady Finger) grown in soil irrigated with domestic sewage water in Sargodha, Pakistan. Arab Gulf Journal of Scientific Research. 32(2/3):169-177.

Kharche, V.K., Desai, V. N. Pharande, A.L. 2011. Effect of sewage irrigation on soil properties, essential nutrient and pollutant element status of soils and plants in a vegetable growing area around Ahmednagar city in Maharashtra. Journal of the Indian Society of Soil Science. 59(2):177-184.

Kumar, Vinod and Chopra, A.K. 2011. Alterations in physico-chemical characteristics of soil after irrigation with Paper mill effluent, 2011, 3(6):722.

Linder, R.C., 1944. Rapid analytical methods for some of the more common inorganic constituents of plant tissues, Plant Physiology, 19: 76-89.

Lindsay, W.L., and Norvell, W.A. 1978. Development of a DTPA soil test for zinc, iron, manganese and copper. Soil Science Society of America Journal, 42, 421-448.

Olsen, S.R., Cole, C.W., Watenable, F.S. and Dean, L.A. 1954. Estimation of available phosphorus in soil by extraction with $\mathrm{NaHCO}_{3}$ USDA. Circular No. 939. 
Omran, A. M., 2010. Long term effect of irrigation with the treated sewage effluent on some soil properties for date palms in Al Hassa, Saudi Arabia. Proceedings of the 19th World Congress of Soil Science: Soil solutions for a changing world, Brisbane, Australia, 1-6 August 2010. Symposium 3.5.1 Heavy metal contaminated soils; 2010:169-172.

Richards, L.A., 1954. Diagnosis and Improvement of Saline and Alkali Soils. Agriculture Hand Book, No.60.USDA. Us Govt.Printing Office, Washington DC. Pp. 1-160.

Subbiah, B.V., and Asija, G.L. 1956. A rapid procedure for determination of available nitrogen in soil.Curr. Sci., 25: 259-260.

Subramani, T., Mangaiyarkarasi, M.,
Kathirvel, C. 2014. Impact of Sewage and Industrial Effluent on Soil Plant Health Act on Environment. Int. Journal of Engineering Research and Applications Vol. 4, Issue 6 (Version 2), June 2014, pp.270-273.

Walkley, A., and Black, C. A. 1934. An Examination of the method for determining soil organic matter and a proposed modification of the chromic acid titration method. Soil sci. 37, 2938

Zan, N. R., Datta, S. P. Rattan, R. K. Dwivedi, B. S. Meena, M. C. 2013. Prediction of the solubility of zinc, copper, nickel, cadmium, and lead in metal-contaminated soils. Environmental Monitoring and Assessment. 185(12):10015-10025.

\section{How to cite this article:}

Hanumant Singh, D.S. Dahiya, Devraj, Md. Sarware Alam, Abhinaw Kumar Singh and Giri, Y.Y. 2017. Application Fate of Sewage and Industrial Effluents on Soil and Plant Health under Karnal District of Haryana, India. Int.J.Curr.Microbiol.App.Sci. 6(9): 2640-2646. doi: https://doi.org/10.20546/ijcmas.2017.609.325 